\title{
A CULTURAL ANALYSIS OF OTTOMAN ALGERIA (1516-1830): THE NORTH-SOUTH MEDITERRANEAN PROGRESS GAP
}

\author{
Tarek Ladjal* and Benaouda Bensaid**
}

\begin{abstract}
A number of works have dealt with the socio-political and economic history of Algeria under the Ottoman protectorate; yet the intellectual and cultural life of this period remains poorly explored. We examine the question of 'progress' against the intellectual and religious life of Ottoman Algeria, analysing the reasons behind the negligent European intellectual influences upon Ottoman Algeria. We review pre-colonial Algeria's cultural and intellectual landscape in order to assess the reaction of Algerian society to European ideas originating in the French Revolution and the Enlightenment. Algeria's intellectual context, learning system, and the public practice of Sufism contributed significantly to building resistance to European intellectual infiltration and influence, while the European communities in Algeria played a marginal role in shaping Algeria's intellectual and cultural life. In spite of its inherent political and geostrategic advantages, Ottoman Algeria failed to achieve a balance between military power and politics in the Mediterranean region, and its own inherent cultural resources.
\end{abstract}

Research into intellectual life in Algeria ( $a l-J a z \bar{a}^{\prime}$ ir) during the Ottoman era necessitates understanding the historical relationships between political and religious authority. The earliest traces of this relationship are found in the first moments of the Turkish presence in Algeria, specifically in the official correspondence in 1519 between the two Barbarossa brothers and the Ottoman Sultan Selim the First (or Selim the Grim d.1520). On this occasion, the Sultan rallied the support of the brothers to assist Ottoman interests in the region under the guise of religious authority and legality, ${ }^{1}$ an initiative which provided the Ottomans with a strong foothold in Algeria. From this beginning of Ottoman presence in Algeria there grew a dialectic relationship between political and intellectual elites, which exercised both a negative and positive impact on the political and cultural scene manifesting in two predominant relationships. There was either contention or agreement, with each predicament enjoying an active presence in Algerian politics. Where one dominates, the other fades into the background and vice versa.

Similarly the Ottoman politics of containment and domestication assisted them in their dealings with cultured Algerians. Such an approach was drawn from the Ottoman realisation that the loyalty of the elites ensured the loyalty of Algerians in addition to constituting a sound strategy for influencing local politics, culture and society. The Ottoman approach is evidenced in the earliest 
examples of Ottoman rule in Algeria, such as when the Ottomans incited the leader of the Muslim campaign against the marauding Spaniards Arrouj (d.1518) and Barbarossa (d.1546) to meet with Shaykh Ahmad bin Yūsuf al-Malyānī (d.1514), a leading figure in the Shadhiliyah Sufi order, and forge an alliance between the al-Malyānī family with the Ottomans which lasted until the end of Ottoman rule in Algeria. The success of this approach led the Ottomans to employ Arrouj and his successors to instigate the allegiance of a large number of learned Families including the houses of Ibn Bādīs, al-Fakkūn, Qaddūrah, and Ibn al-Qāḍī. These Families provided invaluable services to Ottoman authorities in times of insurrection and political turbulence.

Ottoman management and administrative scheme in Algeria had a profound impact on boosting the authority of the intelligentsia as shown in the special official posts offered exclusively to intellectuals including Judges, Muftis, the Khaznajī (state treasurer), Shaykh al-Balad (village headman), Naqīb al-Ashräf (the head of the Ashraf group), Qā'id al-Dār, Bāsh Kätib (secretary), Bāsh Sayyār (caravan manager), and Amin al-Sakkah (market inspector). The judiciary system attracted the largest number of cultured persons. It consisted of two chief judges, one from the Mālikī School of law and the other from the Hanafî School; Muftis; endowment managers; government representatives; and officers. The judiciary was extensive in application in that it encompassed all cities, coastal areas, towns and villages. ${ }^{2}$ The extensive administrative system with its numerous positions of authority was instrumental in containing and managing the Algerian cultured class as it provided them with powers, wealth and exclusive privileges.

However, the policy of persuasion, flattery and domestication was not always successful, as history bears witness to a dispute between higher Ottoman authorities and local administrations. This predicament led to the development of alternatives in the history of the cultural landscape as a result of the many injustices towards local scholars which drove the majority of them to migrate to other countries or even flee from the reach of the Ottomans. We can convincingly claim that the majority of insurrections that plagued Ottoman rule in Algeria were directly led or guided by some notable intellectual and popular religious scholars. The revolt of Yahya al-Awrāsī and his brother Ahmad in the seventeenth century, of Ahmad al-Zawāwī, and of Muhammad al-Ghurāb (d.1792) against the authority of Alī Șālih Bey (d.1792) in Constantine are instructive examples.

The revolts of Darqāwah (d.1802) in the West, and of Ibn al-Ahrash (d.1803) in the East represent two important events in the political and cultural history of Ottoman Algeria. These revolts against the Ottomans were deeply reflected in the culture of the time, which prompted the Ottoman administrators to review their policies by withdrawing their trust from local religious authorities, ${ }^{3}$ and establishing schools and institutes to counter the authority and influence of the 
leading Sufi educational institutions of the Zāwiyah and the Murābițūn (see further below). ${ }^{4}$ However, this led to the loss of many scholars who suffered from restrictions and harassment imposed by the Turks on Algeria's educational and cultural symbols. This harassment was experienced by a good number of prominent scholars the likes of Abū Rās al-Nāșirī (d.1823) who wrote a book on the Darqāwī wars entitled Dar' al-Shaqāwah fī Hurūb Darqāwah; by Muhammad al-Zajāy (d. 1828); and by the leader of the al-Qaytanah Zāwiyah Shaykh Muhammad Muhȳī al-Dīn (d.1833), and his famous son al-Amīr 'Abd al-Qādir (d.1883) who were both prevented from travelling to Mecca for Hajj. Also among these scholars were Ibn al-Qandūz al-Tawjīnī (d.1828) who was killed by the Turks in Māzūnah-just as the noose was tightened on Ahmad alTijānī (d.1815) until he fled to Morocco. Al-Shārif ibn Takūn (d.1851) also fled to Morocco, whereas Muhammad ibn 'Alī al-Sanūsī (d.1859) fled to Mecca. Such events limited the effectiveness of the educational reforms adopted by the Turks in the later period of their rule. The pre-nineteenth century roots of these Algerian intellectuals have to be grasped in proper historical perspective.

\section{SUFI DOGMA: INSTITUTIONS AND PRACTICES}

\section{A. Institutions}

The intensification of the struggle during the fifteenth and sixteenth century between the Spanish and Muslims in Algeria, along with weak political systems of that period, led to the development of an alternative authority in the form of the Zäwiyah. This was a characteristic N. African Sufi institution comprising a self-financed congregation and teaching centre led by a master affiliated with a recognized Sufi Order, often built in the mountains and rural areas. The first Zāwiyah to appear in Algeria was that of Shaykh Sa'ādah, near Toulga, in the fourteenth Century. ${ }^{5}$ This emerging authority was destined to play an active role in Algerian politics, culture and society although it did not manifest itself in any single definite form. Its educational and religious dimensions and its role in society earned popular legitimacy. This resulted in a powerful influence on the opinions of the general populace and future political authorities. Zāwiyah influence spread quickly seeing strong expansion in the $16^{\text {th }}$ century until it reached a wide audience by the second half of the eighteenth century and the first-quarter of the nineteenth century $^{6}$ - up until the eve of the French occupation. According to Dupont and Coppolani, there were twenty three Sufi Orders (tarīqahs) with 295,189 members and 349 Zäwiyahs. ${ }^{7}$ This favourable environment allowed Sufi institutions and practices to continue influencing the religious and intellectual thought and practices of the majority of Algerians for approximately three centuries. 
Undoubtedly the nature of the new immigrants to Algeria, namely Ottoman Turks, contributed in one way or another towards opening up the path for Sufi institutions to emerge, since Ottoman Turks harbour a significant amount of loyalty and obedience towards Tașawwuf and its practitioners. The darāwīsh (Sufi practitioners) had assisted the early Ottoman dynasty in consolidating their authority over Anatolia, just as they had assisted in the conquest of Constantinople. Perhaps the most famous of their masters at the time is al-Hājj Muhammad Bakdāsh (d.1753) in the eighteenth century, ${ }^{8}$ after whom the Bakdāshīyah Sufi order is named and which conveniently established for itself a presence in Ottoman Algeria by way of Turkish administrators and Janissaries. From the earliest beginnings of the Ottoman administration of Algeria, its fondness towards Tașawwuf was reflected in its dealings with its local administrators and allies in which its political agenda was conveniently invested. Beyray Rays for example, notes how in the year $901 \mathrm{AH}$ he and his uncle Kamāl Rays (the leader of the revolt) retired to the Zāwiyah of Shaykh Muhammad al-Tawātì (d.1612) in the city of Bejaia where they stayed for two winters as a sign of love and respect for Shaykh Muhammad al-Tawātī. They both used to spend their summers pursuing Jihäd. Rays also notes that they both felt safe and secure in the city by virtue of the Shaykh's protection. ${ }^{9}$

The alliance between Ottoman Turks and Sufi masters (shuyukh) brought about a noticeable spread and domination of Sufi thought, which in turn led Algeria under Ottoman rule to attract migrating Sufi orders from East and West. In addition to the Qādirīyah Sufi order (founded in Baghdad by 'Abd al-Qādir al-Jīlānī d.1198), the Shādhilīyah order made its way into mainstream thought and practice in Algeria. In the latter-half of the $13^{\text {rd }} / 19^{\text {th }}$ century an attempt to document the number of Sufi Orders in the region found there were thirteen orders from an original number of sixteen, all of which had Shādhilīyah origins. ${ }^{10}$ This supports the view that Sufism in Algeria was not born in Algeria, but was the result of a number of strong eastern and western influences. Even the Raḥmānīyah Sufi order established by Shaykh 'Abd al-Raḥmān al-Azharī (d.1793) at the beginning of the nineteenth century in Algeria, cannot be certain of its Algerian roots since its peculiar Algerian nature was witnessed in the practices of the Khalūtīyah Order by its founder Shaykh 'Abd al-Raīmān al-Azharī during his sojourn in Egypt and Darfur.

The intimate relations between the provinces of Western Algeria and the Sufi organizations of Morocco led to the spread of Sufism into Eastern Algeria and consequently a larger Sufi presence there. The Tijānīyah, Hanșālīyah, Raḥmānīyah, and al-Shābīyah Orders flourished in the East while the 'Īsāwīyah, al-Qādirīyah, al-Azayānīyah and al-Darqāwīyah dominated the Western regions. ${ }^{11}$ During Ottoman rule, the Zāwiyahs of 'Abd al-Raḥmān al-Tha'ālabī and al-Walī Dādah 
and 'Abd al-Qādir al-Jīlānī were the most prominent in the capital city Algiers, while after the French colonial occupation there were thirty two Süfì domes and shrines along with twelve Zāwiyahs. ${ }^{12}$ The Zāwiyahs of Sīdī al-Manātịīi, Sìdī 'Abd al-Mu'min, Sīdī Msīd, and Sayyid Rāshid were prominent in the eastern city of Constantine, which hosted more than sixteen Zāwiyahs. The Zāwiyahs of al-Qayțanah, Sīdī al-Zīib, Sīdī Boumediène, Muhammad al-Sanūsī, and Aḥmad al-Ghumarī were prominent in the western regions of Algeria; while Zäwiyah Khingat Sīdī Nājī and Muhammad ibn 'Alī al-Majjājīi, the khalwah (Sufi retreat) of 'Abd al-Raḥmān al-Akhḍarī, and the Tomb of Sīdī Khālid were prominent in southern parts of Algeria. However, the Berber provinces of Zawāwah and Bejaia hosted more than fifty Zāwiyahs - the most famous being those of Tīzì Rashīd, Sīdī al-Azharī and Ibn 'Alī al-Sharīf in Āqbū. ${ }^{13}$

\section{B. Practices}

The inevitable infiltration of materialist values into Tașawwuf resulted in the loss of much Sufi spiritual ethos, and most importantly the loss of its role in education. It also caused a transformation in the trajectory of Suf thought causing it to lose its position in educational leadership, accompanied by promotion of reclusive values such as abstinence from social and worldly life. On the one hand this mindset gained currency among the oppressed, while on the other hand it led to the "emergence of a religious priestly group of people who were used to resist science and philosophy." 14 This development contributed towards the withdrawal of rational and intellectual thought from the cultural and knowledgeable spheres in society. It then paved the way for blind religious following and shallow Sufi practices which were mostly preoccupied with commentaries on religious works and commentaries upon those commentaries, and with repetitive supplications and praises, while their praxis did not exceed dancing to drums and issuing of amulets. Such practices shocked European travellers, leading some to describe Algeria's cultural situation at the time as consisting predominantly of magic, and that their religious scholars were mere magicians. ${ }^{15}$

This domination of Sufism in popular practice also led to a form of intellectual monotony which marginalised reason, thereby creating an intellectual regression which encompassed society. Perhaps the weakness of the Sufi masters and the intellectual elite, many of whom had become illiterate, ${ }^{16}$ explains their favourable stand on the infiltration of superstitious thought and the doctrines of divine deferment into the intellectual or non-intellectual makeup of their disciples. This state of affairs intentionally or unintentionally subjugated the general public through broadening the boundaries of the 'imaginary' in the minds of Algerians as a result of a decline in learning and culture, as well as the absence of science and rational disciplines from their education. As an example, we point to the idea 
of the divine Will and Destiny with its effects on the practical life of society, which reveals a crucial aspect pertaining to the declining of Sufism in Algeria and its impact on public life. Thus the leading seventeenth century scholar Muhammad al-Būnī (d.1609) called for the complete exclusion of reason from the field of human thought and the disregard of medicine. He further asserted that humans have no free will and that trials of retrogression, oppression and corruption are caused by God for certain beneficial purposes known only to God. Therefore, there was no need for humans to cry out against oppression, oppose their oppressors, or even criticise those who caused retrogression. ${ }^{17}$

\section{THE EDUCATIONAL SYSTEM}

\section{A. Learning Institutions}

\section{Qur'an Schools (al-Kuttāb)}

Qur'an schools represented small often simple establishments concerned to train children from dirtying places of worship. ${ }^{18}$ In these schools, children learnt basic Arabic and basic knowledge skills including writing, reading, and memorising the Qur'an, while also beginning to learn selected legal and linguistic texts. Qur'anic schools played an important role in the preservation of Algeria's national identity. Such schools increased in number and popularity immediately after the French colonial campaigns in reaction to the popular policy of obscurantism in local affairs and the policy of Christianisation pursued by French authorities. ${ }^{19}$ Statistics on the number of local Qur'ān schools during this period are conflicting due to the challenge of differentiating between Qur'ān schools, Zāwiyahs, and other local teaching institutions. It is reported that there were more than one hundred Qur'ān schools in Algiers alone. ${ }^{20}$ In Casbah alone there were eight Qur'ānic schools, ${ }^{21}$ and ninety in Constantine. ${ }^{22}$ The inexpensive set-up costs and their simplicity meant Qur'ānic education was wide-spread, which explains the then low percentage of illiteracy in Algeria.

\section{Zāwiyahs}

Perhaps the most important characteristic of the culture of Ottoman Algeria was the activity of the Zäwiyahs. Originally Zäwiyahs were established for warrior-ascetics, but later were turned into places for reflection, asceticism and memorising the Qur'an. This religious phenomenon led to the prevalence of asceticism and mysticism where the tombs of Sufi masters were located. Zäwiyahs were generally viewed as places in which materiality met mysticism. ${ }^{23}$ Perhaps their most important characteristic is the idea of wholehearted devotion resulting 
in unconditional loyalty and submission to the authority of the Shaykh (whether a living teacher, or a deceased saint). Furthermore the Zäwiyah contributed in important ways to religion, education, politics, and social works. Although many Zäwiyah Shaykhs were illiterate, they exercised an incredible influence over their disciples. ${ }^{24}$ This partly explains the negative contribution of certain Zāwiyah institutions upon the cultural life of Algeria.

Nevertheless some Zäwiyahs had a marked positive influence on the intellectual, social and political scene in Algeria, which slowly facilitated the emergence of prominent scholarship and Jihäd. Many of the scholars emerging from those Zāwiyah turned to institutions of higher education and taught a religious curriculum similar to the major centres of Zaytūnah or al-Azhar. ${ }^{25}$ Many Zāwiyahs like those maintained by the Sanūsīyah and the Tỉjānīyah orders contributed greatly to the spread of religion in far regions of sub-Saharan Africa. Other Zāwiyahs organized and led political-military action against the Ottomans and then the French occupiers.

\section{The Madrasah}

Abū Rās al-Nāșirī defined the "madrasah" as that structure "built for the study and teaching of all forms of learning." ${ }^{26}$ According to the constitution of the madrasah, the move to the second stage was not systematic as the responsibility falls on the will of the student or parents. This second stage ${ }^{27}$ consisted of two distinct levels. ${ }^{28}$ The madrasah contributed to the activation of cultural life in Algeria, especially in expanding urban areas.

\section{Higher Education}

The absence of official recognition of its authority made it difficult for institutions of higher learning to achieve stability. This caused many of its students and scholars to leave Algeria in search for better opportunities for higher intellectual attainments. In Algiers there were al-Qashāshīyah and al-Andalusiyīn; ${ }^{29}$ in Tlemcen the Madrasah al-Jāmī' al-'A'zam and the Madrasah Wādì Imām; in Bisakra the Madrasah al-Khanqah; ${ }^{30}$ and in Constantine there were Āl alFakkūn, Ibn Āfūnās and al-Kitānīyah. ${ }^{31}$ In his memoirs General Beidou reported an official census according to which the number of students in institutions of higher learning in 1837 in Constantine alone was between six to seven hundred, whereas by 1850 this dropped to only sixty students. ${ }^{32}$ The reason for this decline was primarily due to political activity by French occupiers towards education in Algeria, especially their policy regarding the system of endowments ( $a w q \bar{a} f)$ supporting these educational institutions - which constituted, as in the case of the entire Muslim world, the primary funding resource for religious and scientific education..$^{33}$ 
From its early days the French colonial regime targeted these financial endowments. The commander of the French campaign De Bermn decreed on September $8^{\text {th }} 1830$ the confiscation of Islamic endowments. The following day he issued another resolution in which he granted himself alone the authority to manage and lease religious properties. ${ }^{34}$ His targeting the massive network of Islamic endowments did not end there, but continued with a series of successive resolutions which sought to completely dissolve Algerian educational institutions, in order to produce a new generation of Algerians steeped in ignorance and illiteracy. This intent is clearly evidenced by the decree of 7 December 1830, the plan of 25 October 1832, the decree of 31 October 1838, the Royal publication dated 24 August 1839, the decree of 30 October 1858, and the law of $1873^{35}$ -all of which sought to completely remove all forms of education in Algeria. Such a policy directly resulted in the rise of illiteracy rates from $14 \%$ before the occupation to $92.2 \%$ by 1901, settling in the year of independence in 1962 at $92 \% .{ }^{36}$ To date, Algeria continues to suffer the consequences of this French imperial policy whereby the generations who lived through the dark days of the French occupation and were victim of their inhumane policies remain alive today. Furthermore, the illiteracy rate in Algeria as of 2008 was 22\% - much of which is the result of the oppressive French campaign. It is hoped that this rate will decrease to $12 \%$ by $2016 .{ }^{37}$ Doubtless this high rate of illiteracy has delayed the process of development and construction in post-independence Algeria.

\section{B. Curriculum}

Any discussion of the methods used in Algerian cultural institutions prior to the French occupation requires the examination of curricula and the teachers. In the Grand Mosque of Algiers there were more than nineteen professors and teachers. A large number of scholars gathered in the military camps who actively contributed to the cultural movement, headed by Abū Rās al-Nāṣirī (d.1823), Bujlāl (d.1790), al-Ṭāhir ibn Hawā (d.1792), Muhammed ibn Zarqah (d.1799), and Ahmed al-Shārīf (d.1807). The city of Constantine equally enjoyed a favourable environment, for during that period there were a good number of prominent scholars who contributed to the development of a learned culture the likes of Mufti Abdul Qādir al-Rāshīdī (d.1780), and the Ḥanafî judge Sha 'bān ibn Jallūl (d.1799), as well as 'Ammār al-Garbī (d.1800), and Muhammad al-'Arabī ibn Mūsa (d.1802). In the beginning of the thirteenth / nineteenth century there was seven learned circles, each with its own teacher in the Grand Mosque of alQayțanah. In the desert of Wādī Șūf was Khalīfah ibn Ḥassab al-Qamārī (d.1796) and Muhammad ibn 'Abd al-Karīm al-Tawān̄i (d.1800) in Tuwāt. ${ }^{38}$

The courses taught and the teaching methods may be summarised according to three distinct stages: 
1. The first generally simple and basic stage is completed either in the mosque or the Qur'an school wherein children are taught the alphabet, reading and writing by a Shaykh or guardian. Following this comes group memorisation of the Qur'an. This first stage often began at the age of six and continued to twelve years. Almost all villages had this type of institution.

2. In the second stage, graduates from the first stage continued their instruction in the mosques attached to Madrasahs and Zäwiyahs. Usually a student would begin memorisation of the fundamental Islamic texts like that by Ibn Ashūr, the Ajrūmīyah, Qatr al-Nadā, the Alfìyah of Ibn Mālik, al-Shātibīyah, and Sullam al-Akhḍarī. At this stage, the curriculum focuses primarily on learning grammar, Islamic law, 'aqīdah (creedal doctrine), hadith, and poetry. This level of instruction was primarily meant for boys - not for girls.

3. The third stage roughly corresponds to the concept of a modern university education since it was purposely provided for those who excelled in the previous two stages. Instruction was more specialised, usually taking place in madrasahs and colleges. At this stage, many future judges and teachers were granted licenses by professors and teachers, opening the door to many graduates to enrol in higher universities such as al-Zaytūnah and al-Azhar for further studies. ${ }^{39}$

The traditional character of this curriculum with the predominance of taqlid brought intellectual stagnation and limited intellectual creativity, which in turn led to the conviction of the learned elites of the time to regenerate productive values by championing modernisation. Methods of learning through memorisation played a significant role in learning and culture and in maintaining a low literacy rate among Algerians. The reason for this may be attributed to the extensive network of mosques, madrasahs and Qur'an schools across Algerian cities and villages. Parents were mainly responsible for the initial education of their children. Europeans visitors were surprised to discover that the majority of Algerians were able to read and write in Arabic. ${ }^{40}$ The German traveller Wilhelm Chamber in 1830-1831 expressed his surprise as follows: "I have searched for an Algerian citizen who is capable of reading or writing but I could not find such a person, while I found plenty in the countries of southern Europe." ${ }^{\prime 41}$ Such a state of affairs is further supported by official French statistics that state that in 1833 the illiteracy rate in France was 53\%, but did not exceed the threshold of 14\% in Algeria. ${ }^{42}$ This is further corroborated by Yahyā Abū 'Azīz's statement indicating that the prevalence of reading and writing during that period was $90 \%$ of the population, while the percentage of those who reached the level of general culture was $60 \%{ }^{43}$ 
Yet this horizontal expansion did not match a vertical growth in curricula or teaching of courses. The reasons probably rest on the then prevailing religious culture and simplicity of thought of many learned people, or the spirit of inertia inhibiting ijtiha $\bar{d}$ and modernising efforts. These may explain the debate surrounding many scholars like Muhammad Zjay (d.1828) in the town of Maaskar regarding his inferences from Qur'an and Hadith, while his opponents would infer rulings through strict observance of the Mâlikī popular legal work by al-Khalīl. ${ }^{44}$ It is in this context that we understand how the curriculum in many instances lacked attention to scientific disciplines such as medicine, engineering or astronomy, which were absent from learning in Algeria during the Ottoman period in such a way that it drew the attention of European travellers. Shaw described this situation as follows: "For a few centuries, philosophy, mathematics, physics, and medicine were generally monopolised by them (Muslims); only to become unknown and understudied in Algeria today." ${ }^{45}$ The little of those disciplines which infiltrated the curriculum was set for limited religious purposes, being used as secondary disciplines to help understand religious teachings. The primary ideas of mathematics were necessary for the calculation of inheritances (fara 'id $)$ ), while astronomy was studied to determine times for prayer. Medicine was only taught to understand certain related prophetic traditions on bodily states ( $\mathrm{ilm}$ al-abdān $)^{46}$

Thus, according to the testimony of Yahyā al-Shāwī on the authority of his father, in the town of Banī Rashīd alone there were three hundred learning circles for teaching the book of al-Murā' $\overline{1}$ and interpretation of the Alfiyat Ibn Mālik (both on Arabic Grammar), but no circles of learning were reported in the fields of engineering, mathematics, natural sciences, chemistry or medicine ${ }^{47}$ or any life sciences. The absence of cultural institutions failed to nourish any socio-cultural transformation of society. One European traveller described his disappointment with the rampant cultural deterioration, and commented: "Ideas die when they do not find a field of continuous reform." According to his report, he would go out to the streets of Algiers to find nothing worth his attention such as a library or a coffee shop with a newspaper. ${ }^{48}$

In his work published in 1869 entitled The History of Constantine during the Beys, E. Vyst compared the progress of learning in the school of Saleh Bey in Constantine with that of the College de France, observing: "If we compare these two, we would find no discrepancy or difference." 49 Vyst's statement merely reduces all differences between these two institutions to their organisation, teachers' salaries, students' scholarships and lodgings - but the standards of learning and education were definitely different. This is substantiated through the testimony of the German traveller Wilhelm Chamber where he argues that many graduates of religious institutes in Algeria would travel to the city 
of Livorno in Italy to acquire European scholarship in different fields. ${ }^{50}$ In addition, the deteriorated health conditions described in reports by the Spanish priest Diego de Haèdo, by Garcin de Tassy (d.1878), and the United States Ambassador William Shaler, all highlight the heavy reliance on herbs, amulets and superstition in medical treatment, explaining the scarcity of western medicine in Algeria. According to reports by the German traveller Marsio, the only pharmacy in Algeria had a few drugs and herbs, with its caretaker 'al-Bāsh Jarrāḥ' ignoring the medical characteristics and benefits of the items he stocked. ${ }^{51}$ According to Simon Pfeiffer there was no a single professional physician during his visit to Ottoman Algeria. ${ }^{52}$

These all confirm the intellectual disconnection between the two regions of the Mediterranean, north and south. The absence of a clear education policy to enhance culture and learning indicates how the political authorities neglected their responsibilities in education and health care. This is understandable in light of the nature of the Ottoman ruling elites and their role in Algeria, since they viewed learning as having little importance to their times. ${ }^{53}$ The ignorance of Arabic language by the ruling elites - who mostly comprised Turkish, Circasian and Alluj from the Balkans as well as Eastern Europeans - contributed to the isolation of Algerian society on account of their increased unfamiliarity with the local context and failure to understand its needs and challenges. According to historical sources, during the entire period of Ottoman rule over Algeria only a few Ottoman administrators mastered the Arabic language, including Muhammad Bay al-Kabīr (d.1799) and Aḥmad Bay (d.1850) both from Kraghla, Muḥammad Bakhdash (d.1724), Ḥusayn Khwāja (d.1706), and Yūsuf Bāshā (d.1637). Significantly it was under their administration that cultural and intellectual activity became more active.

Furthermore, chaotic political conditions combined with social injustices contributed to the weakening, if not outright destruction, of cultural and intellectual values acquired in the existing colleges and schools. In his work on the intellectual culture and level of students in Tlemcen, al-Zayyānī (1749-1809) provided us with concrete realities showing the stagnation or even failure of the educational system during that time. He remarks, "None of those students in Tlemcen master logic, language, nor Arabic to remedy the tongue. They neither mastered the legal rulings nor the Hadith traditions." ${ }^{54}$ The frayed conditions further undermined the cultural and social spheres animating the moral fabric of values in Algerian society. Had it not been for the presence of religion and for the legacy of earlier centuries, those values may very well have eroded entirely. It is in this context that we should understand the disappointment of al-Wartilānī who during his travels observed learning standards and institutions and described how the ruling power marginalised learning. ${ }^{55}$ In the same context belongs the 
characterisation by the scholar Abū Rās al-Nāṣīin of the academic and cultural conditions in Algeria during late Ottoman rule: "I am in an era where scholarship and its institutions are dysfunctional. Its sources and channels have been shut. It's abode and functions have been transformed, and its features and history have been forgotten." 56

However, this poor state of affairs was not the essential character of Algerian life throughout Ottoman rule, for major political transformations occurred including the French Revolution, Napoleon's expedition to Egypt, and the rise of Algerian authors who believed in change and a modern state born in the French Revolution. This new trend was represented in Muhammed Ibn al-'Annābī (d.1851) and Hamdān Khwājah (d.1845) who were educated in both the Islamic heritage and European culture. They both overlooked the serious implications of the French Expedition to Egypt, and the power and modernisation of the French military. A jurist like Ibn al-'Annābī introduced daunting critical ideas regarding the need and necessity for Revolution in the cultural-political-educational systems and to learn from European progress, while blaming the prevailing Sufi culture for social backwardness. Thus he issued a verdict urging the obligation of removing all dervish propaganda with impunity. His work on military reform al-Say' al-Maḥmūd fī Niẓām al-Junūd gave a reform constitution embracing his concepts and views on change. ${ }^{57}$

\section{FOREIGN PRESENCE AND CULTURAL INTERACTION}

The fall of Granada, the increase of Spain's military might, and repeated wars between Islam and Christendom in the Western Mediterranean resulted in a general growing emotional hatred among residents of the Southern Mediterranean to everything European. Those wars sustained a state of mutual denial and rejection, inherent in the collective unconsciousness ever since the earliest interaction between Muslims and Christians in Andalusia, then the Crusades, until the might of Ottoman conquests in Eastern and Central Europe. This helps explain the state of isolation endured by nations of North Africa, which represented in the historical imagination an unshakable shield for the religion of Islam against all enemies of their Faith. The state of affairs in the Northern Mediterranean was not very different from that existing in the South Mediterranean.

Beginning from the fifteenth century Ottoman and Algerian military expeditions into Europe resulted in several defeats for European powers, feeding an image of Algerians in the European imagination as "The scourge of Christendom. ${ }^{" 58}$ A great number of adventurous individuals from all over Europe entered Algeria, while the percentage of diplomats, ambassadors, 
business people, and priests was relatively small in the representation of Europeans in Algeria. The list of those people from among the Europeans who were able to record their impressions and observations on Algerian society in the form of works and travelogues remain instrumental for understanding peculiar details of the socio-cultural life of that era. A significant number of historical and literary works written during this period deeply shaped the European imagination of Muslim Algerians as rude and uncivilised, largely the result of successful Ottoman and Algerian military expeditions in Europe. ${ }^{59}$ These works were composed by Europeans who interacted with Algerian society either through business, diplomacy, travel, Christian proselytisation, or as a result of captivity. This latter form of interaction, namely captivity, covered most of the European Christian presence in Algeria from the eighteenth century until the end of Ottoman rule. Upon his departure from Algeria in 1567 Hasan Bāsha bin Khayr al-Dīn left a number of Christians and slaves, "among them, was a large number of artists, fluent in many languages and beneficial in many fields." ${ }^{60}$ Towards the end of the sixteenth and throughout the seventeenth century, the number of prisoners of war reached $25,000 .{ }^{61}$

In the eighteenth century official European representation within Ottoman Algeria was empowered through a variety of institutions. Europeans had consular representation with seven consulates, as well as courts, hotels, commercial depots and churches. ${ }^{62}$ The Jews, whose presence in North Africa dates back to earlier historical times, were known as the Jewish Residents or Toshavim. Their presence significantly increased with the migration of Spanish Jews (the megorashim) after the Inquisition; and their influence in the seventeenth century was augmented with a second wave of migration from Livorno in Italy. The immigrant European Jews controlled Jewish groups in Algeria, and dominated foreign trade until the era of the French occupation. ${ }^{63}$ According to one European consul, the number of Jews was thirteen thousand in Algiers alone, ${ }^{64}$ with fourteen synagogues ${ }^{65}$ They maintained active religious and cultural relations with their counterparts in Florence, Marseilles, Amsterdam, London and other European cities. Due to their cultural differences and living standards, there arose a serious conflict between these two Algerian Jewish communities. The Toshavim represented the conservative character influenced by the civilisation of the Middle East, while the megorashim and the Livornoians exhibited a significant degree of Western influence in absorbing modern European culture.

It was this mixed makeup and ethnographic diversity of Algerian society hosting Arabic, Turkish, French, English, Spanish, Italian, German, Dutch and other languages, which confused the German traveller Wilhelm Chamber who was unable to determine their sources. ${ }^{66}$ Such cultural and linguistic diversity raises the interesting question of the effect of those diverse groups and races on 
Algerian cultural life. What intellectual and technical impact did they exercise upon society at large, especially considering that many European captives had direct interaction with the public, with many of them embracing Islam and choosing Algeria as their abode of residence? To answer this question is difficult due to the scarcity of historical data for explaining this interaction. Supporting the challenging position of researchers on the question of cultural interaction may be John B. Wolfe's assertion that European authors and travellers had less chance to interact with Algerian residents, ${ }^{67}$ in addition to the psychological reaction resulting from fanaticism or from mutual hatred and rejection, as argued by Andrew C. Hess. ${ }^{68}$

One may explain the infiltration of ideas issuing from the French Revolution and its effects on Algerian socio-cultural domains through those very same channels. Yet the state of isolation and closeness is not explained by any of the above considerations. Aḥmad bin Sahnūn (d. 1796), the official secretary for the Bay of the city of Oran, commented on the French Revolution saying it was a local issue for the French unbelievers, while he prayed for their destruction. ${ }^{69}$ As was the case with Abū Rās al-Nāṣirī who witnessed the Napoleonic conquest of Egypt, being concerned with showing its negative sides while ignoring the power and modernisation of the French Army. Clearly Algeria's system of governance suffered from degeneration and corruption, while the authority of religious thought and the deterioration of learning all contributed to inhibiting the transfer of European technology, such as printing or industrial machinery, in addition to modern intellectual and literary ideas.

\section{Conclusion}

Intellectual life in Algeria prior to French occupation was not lacking in institutions or organizations, but was in need of a spirit of innovation and educational reform. This is partly indicated by the large number of schools, which exceeded those found in Europe, yet possessed a different quality of instruction. The underlying roots of the deteriorating quality of education sprang from the predominance of an otherworldly religious spirit and attitude affecting the general character of culture and learning institutions. Religious sciences were overly focused on tradition and lost sight of the importance of the natural sciences. Attitudes of complacency and reproducing past historical achievements became prevalent among the intellectual elite. The stultifying effects of Sufism coupled with the absence of modernisation were not the only causes for intellectual deterioration, since the prevailing political culture also played a significant role in Algeria's deterioration. The military maritime nature of Ottoman Algeria was greatly 
concerned with the doctrine of encountering the Northern Christian world and prevention of its military expansion into the Maghreb, negatively affected the development of learning and further marginalised the importance of a progressive intellectual culture.

Beyond these factors, the predominance of cultural blindness in most classes of the Ottoman military elite was bound to have an impact on their stance towards education and intellectual institutions. Historical sources hardly allude to any interest on the part of the Ottoman ruling elites in regard to building or sustaining schools - to the same extent they performed with construction of forts, fleets, and castles. To a large extent this cultural imbalance justified the traditional reliance of educational institutions upon waqf funds, and precluded any reforming for curricula and intellectual life. These factors mitigated against the infiltration of ideas stemming from the European Enlightenment north of the Mediterranean. Rather, local learning was preoccupied with fatwas of prohibition or condemnation of heresy. The ruling class perceived all that came from the north to be an imminent danger that should not be trusted, even if it were an intellectual or scientific product with utility or benefit. The resistance to Europe's intellectual influence was manifested in the contributions of Hamdān Khwājah and Muhammed bin al-'Annābī, and by the resistance to any enlightenment initiated by European travellers, adventurers, or writers living or visiting Algeria during the late Ottoman period.

This situation worsened under the French occupation of Algeria which sought the complete demolition of the educational system through its confiscation of endowments, preventing new schools from opening, and plunging the country into the chaotic depths of illiteracy lasting one hundred thirty-two years - whose effects Algeria continues to suffer today. Our study effectively underlines the significance of cultural depth in defining cultural policy relevant to modern science and culture. We propose the following policy points to serve as productive avenues for cultural implementation when planning for modernisation.

- Intellectuals and educational experts should conduct broader and deeper research into the significant role played by cultural resources for revitalising curricula throughout all levels of education. Disparity in educational structures and corresponding intellectual activity may disclose weaknesses and gaps to be intelligently addressed through more adequate resources and better training; or strengths which require sustaining and consolidation.

- Reflection grounded on historical understanding shall throw light on the conscious configurations of the socio-political fabric in the South Mediterranean: it was ill-equipped to 'catch up' with European progress, 
then failed to confront encroachments from the North that came not only in the form of military and political confrontation, but also in the form of imported ideas, cultural hegemons and discordant worldviews. This reality is still quite relevant to present day societies across the Islamic world, and more awareness of these factors are pertinent for contemporary issues.

- These studies must be integrated with the growing attention paid by Muslim intellectuals to factors affecting the specific mode of modernity achievable by Islamic nations in various fields (economic, financial, educational, and political); and requires intensive research into the cultural failings of the Muslim world at large, with its evident inability to overtake or surpass globalised Euro-American cultural dominance.

\section{Notes}

* Tarek Ladjal is a Senior Lecturer at the Department of History and Islamic Civilization; he was previously a lecturer at the Department of Islamic Studies in International Islamic College University Selangor Malaysia. Tarek obtained his Masters in Theology and Comparative Religion from Emir University at Constantine Algeria, and his PhD Degree in Modern Muslim World History and Civilization at University Malaya, Malaysia. Tarek has published various papers in his field. He is currently the Co-Director of the Malaysia Middle East Relation (MMER), Academy of Islamic Studies University Malaya. Tarek is an expert in Muslim World, Islamic History and Civilization, Islamic though and culture, Sufism and politics, History of Muslim Relation, Islamic reform movements, He has led several research projects and conducted variety of research and publications in different issues. He can be contacted at tarekladjal@gmail.com

** Dr. Benaouda Bensaid earned his Ph.D. in Islamic Studies from McGill University, Montreal, Canada. He has over 18 years of experience in teaching and administration in Canada and overseas. Dr. Bensaid specialises in various subjects of Islamic studies including Islamic thought, Islamic ethics, Islamic law, Islamic mysticism, and modern Muslim movements. Dr. Bensaid has been instrumental in founding several Islamic projects in Canada, and has delivered numerous workshops and lectures on various Islamic topics. Dr Bensaid was working for UM since 2009, now he is associate Professor in Effat University in Jeddah S. A.

1. Unknown author, Ghazawāt Arrj wa-Khayruddīn, Ed. Nūr al-Dīn 'Abd al-Qādir (Algeria: al-Mațba'ah al-Tha'ālibīyah, 1934) 27.

2. 'Abdul Raḥmān al-Jilālī, Tārikh al-Jaz'ir al-'Ām, (Algiers: Dār al-Thaqāfah, 1984) 5-11, 286, vol. 3, 519.

3. M. bin Maymūn, Al-Tuhfa al-Mardiyyah fì Akhbār al-Dawlah al-Bakdāshiyah, ed. M. bin 'Abd al-Karīm al-Jazā'ìrī (Algeria: NCPD, 1972) 253.

4. Abū 1-Qāsim Sa'd Allah, Tārīkh al-Jazā'ir al-Thaqāfì (Beirut: Dār al-Gharb alIslāmī, 2000) vol. 2, 267.

5. Ahmidah 'Amirawī, Muḥaḍarāt fì Tarīkh al-Jazā ir al-Hadīth, (Algeria: Dār alHudā, 2004) 24. 
6. Masūd al-'Īd, “Al-Murābițūn wa al-Ṭuruq al-Șūfìyah bi-l-Jazā'ir khilāl al-'Ahd al-'Uthmān̄̄", Journal of Social Sciences [University of Constantine, Algeria] 13 (1988) 35-51.

7. Coppolani X. Depont, Les Confreries Religieuses Musulmanes (Montréal: Maisonneuve, 1897) vol. 1 p. 257.

8. Sa'd Allāh, Tārīkh al-Jazā'ir al-Thaqāfì, vol. 4, 198.

9. Ibid. vol. 1, 464.

10. Ibid. vol. 4, 266.

11. For basic orientation regarding these Orders, their organization, and the institution of the zāwiyah, consult John Spencer Trimingham, The Sufi Orders in Islam (Oxford: Clarendon Press, 1971).

12. Sa'd Allāh, Tārīkh al-Jazā'ir al-Thaqāfì, vol. 4, 266.

13. Ibid. vol. 2, 246-267.

14. J. Desmond Bernal, Science in History (London: Penguin, 1969) 1-12.

15. Ibid.

16. Yahyā Abū 'Azīz, "Awda' al-Mu'assassāt al-Dīnīyah bi-l-Jazā'ir khilāl alQarnayn al-Tāsi “wa-l- 'Äshir," in Majallat al-Thaqäfah," 17 (1981) no. 13, 347

17. Sa'd Allah, Tārīkh al-Jazā’ir al-Thaqāfì, vol. 1, 478.

18. Abū 'Azīz, op. cit. 13.

19. Ibid.

20. 'Abd al-Raḥmān al-Jilālī, Tārikh al-Jazā'ir al-'Ām (Algiers: Dār al-Thaqāfah, 1984) vol. 3, 451-540, 537-552.

21. Abū 'Azīz, op. cit. 13.

22. Abū 'Az̄iz, Ma'a Tārīkh al-Jazā'ir: Multaqayāt al-Wațan̄yah wa l-Dawlīyah (Algiers: OUP, 1999) 347.

23. Maḥ̂ū Dammūm, al-Thaqāfah wa al-Muthāqafah fì al-Mujatama' al-Hadarī khilāl al-'Ahd al-'Uthmān̄̄ (Masters Thesis: Algeria: University of Emir Abdelkadir, 2002), 100.

24. Abū 'Azīz, op. cit. 17.

25. Sa'd Allah, Tārīkh al-Jazā'ir al-Thaqāfì, vol. 3, 263-266.

26. Abū Rās al-Nāșirī, Fath Allāh wa-Minnatuh fì al-Tahadduth bi-Fadl Rabbī wa-Ni 'matih, ed. Muhammad al-'Arabī al-Zūbīin̄ (Algeria: The Office for University Publications (OUP), 1986), 34, 76-77. (Generally in the present era, the madrasah is equivalent to primary and secondary school education in many Muslim societies.)

27. According to the statement made by Senator Combs in the interests of the French Congress, there were more than two thousands high schools; (al-Jilālī, op. cit. 1984, vol. 3, 538).

28. Al-Nāṣirī, Fatḥ Allāh, 76; Sa'd Allah, Tārīkh al-Jazā'ir al-Thaqāfì, vol. 3, 221.

29. Al-Nāșirī, op. cit. 34.

30. Sa'd Allāh, Tārīkh al-Jazā'ir al-Thaqāfì, vol. 1, 284.

31. Aḥmad T. al-Madan̄̄, Mohammed Othman Basha (Algeria: National Book Foundation (NBK), 1986), 153.

32. Al-Jilālī, Tārikh al-Jazā' 'ir al- 'Ām, 540.

33. Wael B. Hallaq, Shari'ah: Theory, Practice, Transformation (Cambridge: Cambridge University Press, 2009), 471ff.

34. DRE [Directorate of Religious Endowments], the Algerian Awqā f, (Algeria: Ministry of Religious Affairs, 2008), 3.

35. Nāṣir al-Dīn Sa 'idūn̄̄ \& Mahdī al-Būabdelli, Al-Jazā'ir fì al-Tārīkh (Algiers: NBK, 1984), vol. 1, 110, 167, vol. 3, 519.

36. Muhammad Bā' Mughlī, The Economic Foundation for the Endowment System in Algeria and its Role in the French Occupation (Algeria: University of Algeria 
Press, 2002), 166.

37. National Office for Literacy Report, Ministry of National Solidarity (Algeria: 2012).

38. Sa'd Allāh, Tārīkh al-Jazā'ir al-Thaqāfì, vol. 3, 276.

39. Yaḥyā Abū 'Azīz, Ma'a Tārīkh al-Jazā'ir; Multaqayāt al-Wațaniyyah wa alDawliyyah (Algeria: OUP, 1999), 337-347.

40. André Brenan et. al., Al-Jaza 'ir bayna al-Māộ̄ wa al-Hāạir (Algeria: OUP, 1984) 211.

41. Abū al-'īd Dūdū, Al-Jazā'ir fì Mu'llafāt al-Rahḥālīn al-Almān, 1830-1855 (Algiers: NCPD, 1975), 2-13.

42. However, Evirett maintains that the percentage of illiterates was less than that of France, and exceeded 40\% during that time; see Brenan, op. cit. 211.

43. Abū 'Azīz, Ma'a Tārīkh al-Jazā'ir, 221.

44. Sa'd Allāh, Tārīkh al-Jazā'ir al-Thaqāfì, vol. 1, 49.

45. John B. Wolfe, The Barbary Coast: Algiers under the Turks 1500 to 1830 (New York: WW Norton \& Co., 1979), 155.

46. Sa'd Allāh, Tārīkh al-Jazā'ir al-Thaqāfì, vol. 3, 186.

47. Al-Jilālī, Tārikh al-Jazā'ir al- 'Ām, vol. 3552.

48. Sa'd Allāh, Tārīkh al-Jazā'ir al-Thaqāfì vol. 1, 166.

49. Al-Jilālī, Tārikh al-Jazā'ir al-'Ām, vol. 3537.

50. Abū al-'Ī̀ Dūdū, Al-Jazā'ir fì Mu'llafāt al-Raḥhālīn al-Almān, 13.

51. J. Laugier De Tassy, Histoire des Etats Barbaresques qui Exercent la Piraterie (Paris: Chez Chaubert, 1757), 211.

52. Simon Pfeiffer, Mudhakkirāt aw Lamhāât Tārikhiyyah 'an al-Jazā'ir, trans. Abū al-'Īd Dūdū (Algeria: NCPD, 1974) 25.

53. Sa'd Allāh, Tārîkh al-Jazā'ir al-Thaqāfî vol. 1, 241.

54. Mawlay Bel Hamissi, Al-JazÉ'ir min KhilÉl RaÍlalÉt al-MaghÉribah fÊ al-'Ahd al-'UthmÉnÊ (Algeria: NCPD, 1981) p. 162.

55. A. al-Wartilānī, Riḥlat al- Wartilān̄̄, ed. Mukhtār Filālī (Batnah: Dār al-Shihāb, 1999) 122.

56. Abū Rās al-Nāșirīi, Fath Allāh wa-Minnatuh, 11.

57. Aḥmidah 'Amìrawī, Muhaḍarāt fì Tarīkh al-Jazā 'ir al-Hadīth, (Algeria: Dār al-Hudā, 2004) 98.

58. See in particular R. Lambert Playfair, The Scourge of Christendom: Annals of British Relations with Algiers Prior to the French Conquest (London: Smith, Elder \& Co., 1884).

59. Such works are found in the Newberry library in Chicago, which has more than forty works written by European travelers and journalists who visited Algeria during Ottoman rule. The French National Library and British Museum preserve more than one hundred titles (Wolfe, p. 171), while the bibliography of Sir Playfair points to the existence of more than 293 works published before 1789 on this particular topic; R. Lambert Playfair, The Bibliography of the Barbary States (UK: Gregg, 1971).

60. Sa'd Allāh, op. cit. vol. 1, 151.

61. Andrew C. Hess, The Forgotten Frontier: A History of the Sixteenth-Century Ibero-African Frontier (Chicago: University of Chicago Press, 1978) 261-271.

62. Al-Jilālī, op . cit. vol. 3, 519.

63. Sa'īdūn̄̄ \& al-Būabdelī, op. cit. vol. 4, 201.

64. John B. Wolfe, The Barbary Coast: Algiers under the Turks, 1500 to 1830 (New York: W.W. Norton \& Co., 1979), 167. Sa'd Allāh, Tārīkh al-Jazā'ir al-Thaqāfī vol. 3, 232.

65. Al-Jilālī, op. cit. vol. 3, 519. 
66. Dūdū, Al-Jazā'ir fì Mu'llafāt al-Rahḥālīn al-Almān, 12.

67. Wolfe, The Barbary Coast, 166.

68. Andrew C. Hess, The Forgotten Frontier: A History of the Sixteenth Century Ibero-African Frontier, 271.

69. Ibn Sahnūn, Al-Thaghr al-Jumānī fì Ibtisām al-Thaghr al-Wahrānī, ed. al-Mehdi al-Būabdelī, (Algeria: NBK, 1980), 225. 